\title{
Which Topics are Important to Address in Pre- marital Counseling? A Survey of Clergy
}

\author{
Christine E. Murray, Ph.D. \\ PO Box 10271 \\ Greensboro, $\mathrm{NC} 27404$
}

Pastoral counselors who provide premarital counseling must address the topics that are most relevant to couples as they prepare for marriage. This article presents the results of a survey of clergy who provide premarital counseling, demonstrating the relative importance that clergv ascribe to premarital counseling topics, as well as the relationship between religious affiliation and ratings of topic importance.

$\mathbf{P}$ astoral counselors often assist couples as they prepare for marriage. Although members of other professional groups also offer premarital counseling, clergy are the most common providers of premarital counseling. ${ }^{1}$ During premarital counseling sessions, pastoral counselors may address a wide range of topics with engaged couples. Because premarital counseling programs average about four hours of contact time with couples, ${ }^{2}$ time limitations render it impossible to address all topics that may be relevant. Therefore, the counselor must attend to the topics that are most pertinent and beneficial in helping the couple prepare for marriage. Following a review of existing research that examines the relative importance of topics in premarital counseling, this article presents the results of a survey of clergy who provide premarital counseling. The results of this survey demonstrate the relative importance that clergy ascribe to premarital counseling topics, as well as the relationship between religious affiliation and ratings of topic importance.

The topics addressed in premarital counseling are intended to bring about positive changes in the premarital relationship in order to enhance the marriage. ${ }^{3}$ The premarital counseling programs that are described in the literature incorporate numerous topics, and topics vary among programs. Commonly addressed topics that are found in the literature include the following: careers, finances, friendship and social support, parenting and children, religion, family of origin issues, attitudes and beliefs toward marriage, gender role expectations, personality characteristics, values, adjusting to married life, commitment to marriage, communication skills, conflict resolution skills, coping skills, emotional management, fun and leisure, the importance of spending time with one's partner, problem-solving, romance, and the sexual relationship. ${ }^{*}$ In addition to these topics, counselors may address client motivation for participating in interventions such as premarital counseling. ${ }^{5}$ Premarital counselors can address motivation by attending to the couple's reasons for coming to premarital counseling and discussing the benefits of premarital counseling.

Previous research examined couples' perceptions of the usefulness of various topics. Russell and Lyster examined consumer satisfaction among participants in a marriage preparation program in Canada. ${ }^{6}$ Their results indicated that participants are generally satisfied with premarital education

The Journal of Pastoral Care \& Counseling, Spring-Summer 2006, Vol. 60, Nos. 1-2 
programs. The order of satisfaction in specific components of the program was as follows: (a) family-of-origin issues, (b) finances, (c) communication and conflict resolution, (d) sex roles and sexuality, (e) children and parenting, and (f) family and friends. In a later report, Lyster, Russell, and Hiebert found that satisfaction in specific program components mar differ according to the context of a couple's marriage.' For example, they reported that couples who are remarrying are more likely to value discussing the topic of spirituality as compared to couples who are entering their first marriage.

Williams and Riley examined the topics that participants in marriage preparation programs view as most helpful. ${ }^{8}$ Several different types of marriage preparation programs nere considered, and all participants in the study were couples who had been married for one to eight vears. The results indicated that nearly two-thirds of couples thought that marriage preparation was a valuable experience. Results also indicated that some aspects were more valuable than others. The researchers suggest that marriage preparation should focus primarily on dealing with the initial transitions of adjusting to married life. For couples in this study, the most raluable aspect of premarital counseling was spending time with one's partner and learning more about him or her. The five most important topics to be addressed in premarital counseling programs were labeled the "five C's": communication, conflict resolution, commitment, church, and children.

Risch, Riley, and Lawler employed a different approach to identifying the topics that are most appropriate to address in premarital counseling. ${ }^{9}$ These researchers surveyed couples in their first five years of marriage in order to identify the most common problem areas faced by newly married couples. Their findings suggest that the most common issues faced by the couples in their sample included balancing job and family, the frequency of sexual relations, financial issues. expectations about household tasks, communication and conflict resolution, family-of-origin relationships, and spending time together as a couple. Risch, Rilev, and Lawler assert that these problem areas are useful topics to address in premarital counseling and educational programs.

The results of these studies suggest that couples do not value all potential premarital counseling topics equally. However, the topics that previous researchers have found to be important vary. Because couples enter premarital counseling with unique life experiences and relationship histories, each couple may exhibit preferences in the topics they wish to address. The present study involves further exploration of the relative importance of topics in premarital counseling programs, based on the preferences of providers. Clergy often have extensive experience in providing premarital counseling. For example, Jones and Stahmann found that clergy who participated in their survey had an average of 17 years of experience providing premarital counseling, and they had seen an average of 8.1 couples for premarital counseling within the previous year. ${ }^{10}$ Therefore, in this study, the perspective of clergy is sought in an effort to identify trends across couples related to the topics that are important to address in premarital counseling.

\section{Method}

This study used a cross-sectional survey research methodology. Participants were providers of premarital counseling in the state of Florida. In Florida, 
the state government offers incentives (e.g., a discount marriage license fee and a waiver of the waiting period to obtain a marriage license) for couples who attend premarital counseling. ${ }^{11}$ Providers of premarital counseling must register with their county clerk of court in order for their clients to be eligible to receive the incentives. Professionals who are eligible to provide premarital counseling include psychologists, clinical social workers, marriage and family therapists, mental health counselors, and representatives of religious institutions. A registry of premarital counseling providers is available in each county. The sample in this study was selected from these registries.

Lists of providers were available from the $51(76.1 \%)$ of the 67 counties in Florida from which registries were made available for this study. From the compiled county lists, 1000 potential participants were selected into the study using a systematic sampling procedure. Although 201 providers who were selected to be part of the study were unable to be contacted due to out-of-date contact information, 210 providers completed the survev. This represents a response rate of $26.3 \%$, not including participants who were unable to be contacted. Of the 210 individuals completing the survey, 167 $(81.46 \%)$ identified their primary professional affiliation as clergy: The responses of only the clergy are reported here.

Each survey respondent was asked to complete a 78-item Premarital Counseling Survey (PCS). One section of the survey asked providers to rate twenty-three topics that are addressed commonly in premarital counseling programs. These topics included (a) adjusting to married life, (b) attitudes and beliefs toward marriage, (c) the benefits of premarital counseling, (d) careers, (e) commitment, (f) communication skills, (g) compatibility of values, (h) conflict resolution, (i) coping skills, (j) the couple's reasons for entering premarital counseling, (k) emotional management, (l) friendships and social support, (m) family-of-origin influences, (n) finances, (o) fun and leisure, (p) gender role expectations, (q) the importance of spending time with one's partner, $(r)$ parenting and children, (s) personality characteristics, $(t)$ problem-solving skills, $(u)$ religion, $(v)$ romance, and $(w)$ the sexual relationship. These topics were drawn from the literature that describes existing premarital counseling programs.

The following research questions guided this inquiry: (a) Which topics do clergy believe are most and least important to include in premarital counseling;; and (b) Do clergy differ in their ratings of the importance of topics based on their religious affiliation: In order to answer the first research question, a rank-order means analysis was conducted. In this analysis, mean scores were calculated for each of the topics. The scores were then ranked according to their means. To answer the second research question, ANOVAs were conducted to compare the topic rating of four categories of participants' religious affiliations: Baptist, Methodist, Nondenominational Christian, and Roman Catholic.

\section{Results}

The clergy who participated in this study represented a range of religious and ethnic backgrounds. The frequencies and percentages of religious affiliations and ethnic backgrounds of the participants are presented in Tables 1 and 2. The average age of respondents was 55.34 years $(\mathrm{SD}=11.05)$. The sample was comprised of $156(93.4 \%)$ males and $11(6.6 \%)$ females. 


\begin{tabular}{lrr}
\hline Religious Affiliation & Frequency & Percentage \\
\hline Anglican & 1 & 0.6 \\
A.M.E. & 1 & 0.6 \\
Assembly of God & 2 & 1.2 \\
Baptist & 51 & 30.1 \\
Disciples of Christ & 3 & 1.8 \\
Episcopalian & 3 & 1.8 \\
Jewish & 3 & 1.8 \\
Lutheran & 12 & 7.3 \\
Methodist & 18 & 10.9 \\
Non-denominational Christian & 16 & 9.7 \\
Pentecostal & 10 & 6.1 \\
Presbyterian & 9 & 5.5 \\
Roman Catholic & 15 & 9.1 \\
United Church of Christ & 2 & 1.2 \\
Other & 19 & 11.5 \\
& & \\
\hline Note Data wred & &
\end{tabular}

Note: Data were missing for two respondents.

TABLE 2

Frequencies and Percentages of Ethnic Backgrounds of Clergy

Ethnic Background

African American

Asian American

Caucasian

Hispanic

Native American

Other
Frequency

$\begin{array}{rr}25 & 15.0 \\ 1 & 0.6 \\ 135 & 80.8 \\ 5 & 3.0 \\ 3 & 1.8 \\ 2 & 1.2\end{array}$

Percentage

15.0

0.6

3.0

1.8

1.2

Note: Respondents could select more than one ethnic background, so the sum of the percentages is greater than $100 \%$.

Of the 167 clergy who responded to the survey, $109(65.3 \%)$ indicated that they had received some form of professional training in premarital counseling. Participants had an average of 20.13 years $(\mathrm{SD}=12.01)$ experience providing premarital counseling and had worked with an average of 7.78 couples $(S D=14.30)$ in the past year. The average length of time that participants spend with couples in premarital counseling was 8.79 hours $(\mathrm{SD}=9.01)$.

The PCS asked the following question about premarital counseling topics: "Based on your experience, how important or unimportant do you feel it is to address each of the following topics in a premarital counseling and/or educational program?" Scores could range from 1 (very unimpor- 
tant) to 5 (very important). The mean scores and standard deviations of the topic items for the total clergy sample can be found in Table 3. Overall, clergy rated the following five topic items as the most important to address in premarital counseling: (a) commitment to the marriage, (b) communication skills, (c) attitudes and beliefs toward marriage, (d) conflict resolution, and (e) the importance of spending time with one's partner. The following five topics were rated by clergy as least important: (a) family-of-origin factors, (b) friendships and social support, (c) careers, (d) the couple's reasons for entering premarital counseling, and (e) fun and leisure.

TABLE 3

Rankings of the Importance of Topics for all Clergy ( $N=167)$

\begin{tabular}{lll}
\hline Topic & Mean & SD \\
\hline 1. Commitment to the marriage & 4.92 & 0.47 \\
2. Communication skills & 4.83 & 0.61 \\
3. Attitudes/beliefs toward marriage & 4.82 & 0.58 \\
4. Conflict resolution & 4.80 & 0.62 \\
5. The importance of spending time with & 4.77 & 0.64 \\
$\quad$ one's partner & & \\
6. Parenting and children & 4.74 & 0.62 \\
7. Adjusting to married life & 4.72 & 0.64 \\
8. The sexual relationship & 4.61 & 0.65 \\
9. Compatibility of values & 4.61 & 0.67 \\
10. Problem-solving skills & 4.54 & 0.78 \\
11. Religion & 4.52 & 0.77 \\
12. Coping skills & 4.52 & 0.78 \\
13. Gender roles/Household tasks & 4.49 & 0.67 \\
14. Emotional management & 4.46 & 0.71 \\
15. Family finances & 4.46 & 0.77 \\
16. Romance & 4.39 & 0.77 \\
17. Personality characteristics & 4.33 & 0.76 \\
18. Benefits of premarital counseling & 4.33 & 0.84 \\
19. Family-of-origin factors & 4.11 & 0.81 \\
20. Friendships and Social Support & 4.07 & 0.74 \\
21. Careers & 4.02 & 0.80 \\
22. The couples reasons for entering & 4.02 & 0.89 \\
premarital counseling & & \\
23. Fun and leisure & 3.99 & 0.78 \\
\hline
\end{tabular}

Note: Date were missing for five respondents

The relationship between clergy's religious affiliation and their ratings of the importance of topics was examined. The topic ratings by clergy representing four categories of religious affiliation were considered: Baptist, Methodist, Non-denominational Christian, and Roman Catholic. These categories represented the largest number of participants. Means were calculated for each topic based on participants' religious affiliations, and the topics were ranked according to their mean scores (Table 4). 


\section{Rankings of the Importance of Topics by Religious Affiliation}

\begin{tabular}{|c|c|c|c|}
\hline Baplist $(\mathrm{n}=\mathbf{5 1})$ & Methodist $(n=18)$ & Non-denominational Christian $(n=16)$ & Roman Catholic $(n=15)$ \\
\hline 1. (commitment $(5.00,0.00)$ & 1. Altitudes toward manriage & '1. Commitment $(5.00,0.00)$ & 1. Altitudes towarel marriage \\
\hline 2. condlict res. $(4.94,0.24)$ & $(1.78,0.73)$ & I. communication $(5.00,0.00)$ & $(5.00,0.00)$ \\
\hline 3. Communication $(4.92,0.28)$ & 2. Communicalıon $(4.78,0.94)$ & 3. Spending time with onc's & 1. (ommminncint $(5.00,0.00)$ \\
\hline 4. Spendelng time with one's & 3. Values $(1.67,0.77)$ & partunev $(4.93,0.26)$ & 'I. Psurenting $(5.00,0.00)$ \\
\hline 5. Patenting $(4.48,0.43)$ & 4. Commitument $(467,0.97)$ & 4. (ionllicl res. $(4.87,0.35)$ & 4. Communication $(4.93,0.26)$ \\
\hline 6. Attitudes towatrd marrage & 5. Adjust. 1o marr. (A.fil, $0 .(j 1)$ & 4. Religion $(4.87,0.35)$ & 5. conllice res. $(4.87,0.35)$ \\
\hline$(4.82,0.53)$ & (i. Finances $(1.56,0.78)$ & (i. Finances $(4.80,0.41)$ & 6. Spendeng time with one's \\
\hline 7. Values $(4.80,0.41)$ & 7. Spending time with one's & (j. Sex $(1.80,0.41)$ & partucr $(4.80,0.41)$ \\
\hline 8. Adjust (o marr: $(4.80,0.54)$ & partmer $(4.5(i, 0.98)$ & 8. Vialues $(4.73,0.16)$ & 6. (opjing skills $(4.80,0.41)$ \\
\hline 9. Sex $(1.73,0.45)$ & 8. $S \times(4.50,0.79)$ & '8. Problelem-solving ( $1.73,0.46)$ & (j. Problem-solving $(4.80,0.41)$ \\
\hline 10. Religion $(4.73,(0.19)$ & 9. Conflict res. $(4.50,0.99)$ & 10. Adjust (o marr. $(4.73,0.80)$ & 9. Religion $(4.67,(0.49)$ \\
\hline 11. (oppung skılls $(1.69,0.47)$ & 10. Parenting $(4.44,0.98)$ & 10. Altitudes toward marriage & $9 . S(\times x(4.67,0.49)$ \\
\hline 'l2. Emonomal man. (4.65, (0.52) & 11. Problem-solvme $(4.39,1.04)$ & $(1.73,0.80)$ & 11. Adjust to marr: (1.67, (0.62) \\
\hline '12. Funances $(4.65,0.52)$ & 12. ender roles $(1.33,0.69)$ & 12. Romance $(4.67,0.49)$ & 12. (iender roles $(4.53,0.52)$ \\
\hline 14. (iender roles (4.50), $(0.57)$ & 13. Roligion $(4.33,0.84)$ & 13. Parenting $(4.67,0.62)$ & 13. Family-ol-orig. (4 47, (.64) \\
\hline 15. Problem-solving (4.58, 0.54) & 11. Lmolional man. $(1.28,0.67)$ & 14. (opping skills $(4.67,0.72)$ & 14. Funances $(4.47,0.71)$ \\
\hline 16. Romance $(4.57,0.50)$ & 15. Romance $(4.28,0.75)$ & 15. Bencelits of premanital & 15. Values $(4.40,0.51)$ \\
\hline 17 Pessomality $(4.47,0.54)$ & l(i. lammly-(0)-(origin $(1.22,0.55)$ & counscling $(4.60,0.63)$ & 16. Personality (4.40, 0.6.3) \\
\hline 18. Benelits of premarial & 17. (ooping skılls $(4.22,0.94)$ & 15. Emotional man. (4.(60), (0.63) & 17. Benclits of premartal \\
\hline counseling & 18. Boncelits of premarital & 17. Persomality $(4.17,0.64)$ & counscling $(4.40,0.71)$ \\
\hline 19. Reasons lor premarital & counseling $(1.17,0.92)$ & is. ciender roles $(1.40,0.74)$ & 18. Emotional man. $(4.33,0.72)$ \\
\hline counscling $(1.39,0.84)$ & 19. Friconds/support (4.11, (0.68) & 19. Calrecers $(4.333,0.72)$ & '19. Romance $(1.33,0.72)$ \\
\hline 20. Family-of-origin $(4.12,0.73)$ & 20. Persomality (4.0) 1.12$)$ & 20. Fut)/leisure $(4.13,0.74)$ & 20. ( iareers $(4.27,0.80)$ \\
\hline 21. Catrecers $(4.12,0.75)$ & 21. lun/leisure $(3.94,0 .(64)$ & 21. liriconds/support $(413,0.71)$ & 21 Friends/support $(4.20,0.77)$ \\
\hline 22. Friends/support (4.08, $0 .(11)$ & 22. (aarecers $(3.72,0.57)$ & 22. Famoly-ol-origin $(4.00,1.00)$ & 22. Reasoms for premarital \\
\hline 23. Fun/leisure $(408)$ & $\begin{array}{l}\text { 23. Reasons for premarital } \\
\text { counseling }(3.72,0.89)\end{array}$ & $\begin{array}{l}\text { 23. Reasous for premarital } \\
\text { commselung }(4.0(0,1.20)\end{array}$ & 23. Fum/le isure $(3.93,0.96)$ \\
\hline
\end{tabular}

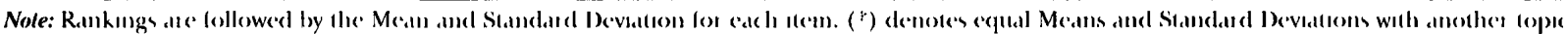

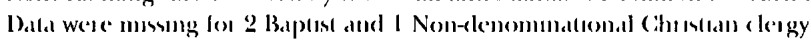


Baptists $(\mathrm{n}=51)$ rated the following topic items as the most important to address in premarital counseling: commitment to the marriage, conflict resolution, communication skills, the importance of spending time with one's partner, and parenting and children. Methodists $(n=18)$ gave the following topic items highest ratings of importance to address in premarital counseling: attitudes/beliefs toward marriage, communication skills, compatibility of values, commitment to the marriage, and adjusting to married life. Non-denominational Christian clergy $(n=16)$ gave the highest ratings to the following topic items: commitment to the marriage, communication skills, the importance of spending time nith one's partner, conflict resolution, and religion. Roman Catholic clergy $(n=15)$ rated the following topics as most important to address in premarital counseling: attitudes and beliefs toward marriage, commitment to the marriage, parenting and children, communication skills, and conflict resolution.

A series of one-way ANOVAs was conducted to determine if there were significant differences in the ratings of topics based on the religious affiliation of the providers. One-way ANOVAs compared group means among the four groups of religious affiliations. Following each ANOV'A, effect size was calculated using the coefficient of determination $\left(R^{2}\right)$. For the coefficient of determination, a small effect size is indicated by an $R^{2}$ value of 0.01 , a medium effect size is indicated by an $R^{2}$ value of 0.09 , and a large effect size is indicated by an $R^{2}$ of $0.25 .{ }^{12}$ The F-score, $p$-ralues, and $R^{2}$ values associated with this analysis are found in Table 5 .

TABLE 5

Summary of One-Way ANOVA Analyses of Topic Comparing Baptist, Methodist, Non-denominational Christian, and Catholic Clergy

\begin{tabular}{llll}
\hline Topic & $\mathbf{F ( 3 . 9 6 )}$ & $\boldsymbol{p}$-value & $\mathbf{R}^{2}$ \\
\hline Adjusting to married life & 0.49 & 0.69 & 0.02 \\
Attitudes and beliefs toward marriage & 0.62 & 0.60 & 0.02 \\
The benefits of premarital counseling & 2.41 & 0.07 & 0.07 \\
Careers & 2.45 & 0.07 & 0.07 \\
Commitment to the marriage & 3.09 & $0.03^{*}$ & 0.09 \\
Communication skills & 0.69 & 0.56 & 0.02 \\
Compatibility of values & 2.34 & 0.08 & 0.07 \\
Conflict resolution & 3.52 & $0.02^{*}$ & 0.10 \\
Coping skills & 3.20 & $0.03^{*}$ & 0.09 \\
The couple's reasons for entering & & & \\
$\quad$ premarital counseling & 1.96 & 0.13 & 0.06 \\
Emotional management & 2.32 & 0.08 & 0.07 \\
Family finances & 0.86 & 0.46 & 0.03 \\
Family-of-origin factors & 1.20 & 0.32 & 0.04 \\
Friendships and social support & 0.13 & 0.94 & 0.00 \\
Fun and Leisure & 0.42 & 0.74 & 0.01 \\
General role expectations/Household & & & \\
$\quad$ tasks & 0.95 & 0.42 & 0.03 \\
The importance of spending time with & & & \\
$\quad$ one's partner & 1.46 & 0.23 & 0.05
\end{tabular}




$\begin{array}{llll}\text { Parenting and children } & 3.18 & 0.03^{*} & 0.09 \\ \text { Personality characteristics } & 1.99 & 0.12 & 0.06^{\circ} \\ \text { Problem-solving skills } & 1.37 & 0.26 & 0.04 \\ \text { Religion } & 3.10 & 0.03^{*} & 0.09 \\ \text { Romance } & 1.90 & 0.13 & 0.06^{\circ} \\ \text { The sexual relationship } & 1.09 & 0.36 & 0.03\end{array}$

Note: ${ }^{`} p<0.05:^{\wedge}$ denotes a small effect size: ${ }^{\wedge}$ denotes a medium effect size

These analyses revealed that five topics were rated significantly different based on religious affiliation: commitment to the marriage, conflict resolution, coping skills, parenting and children, and religion. For each of these significant findings, unpaired $t$-tests were conducted to determine which groups differed significantly from one another for each topic rating. For all five topics, Baptist clergy differed significantly from Methodist cler$\mathrm{gy}$, with the following values for the $t$-test, degrees of freedom, and corresponding two-tailed $p$-values: commitment to the marriage $(t-2.41, \mathrm{df}=65$, $p=0.02)$, conflict resolution $(t=2.92, \mathrm{df}=65, p=0.005)$, coping skills $(t=2.72$, $\mathrm{df}=65, p=0.009)$, parenting and children $(t=2.33, \mathrm{df}=65, p=0.02)$, and religion $(t=2.41, \mathrm{df}=65, p=0.02)$.

There were no other differences in ratings for two topics: commitment to the marriage and conflict resolution. Ratings of the importance of the topic of coping skills differed significantly between Methodist and Roman Catholic clergy $(t=2.22, \mathrm{df}=31, p=0.03)$. Ratings of the importance of the topic of parenting and children differed significantly between Methodist and Roman Catholic clergy $(t=2.21, \mathrm{df}=31, p=0.03)$ and Non-denominational Christian and Roman Catholic clergy $(t=2.06, \mathrm{df}=28, p=0.05)$. Also, ratings of the importance of the topic of religion differed significantly between Methodist and Non-denominational clergy $(t=2.32, \mathrm{df}=31$, $p=0.03$ ).

Although they were not of statistical significance, all but one of the other topic ratings indicated a small effect size based on participants' religious affiliation. The only topic for which an effect size was not found was friendship and social support. The presence of these small effect sizes, in the absence of statistical significance, suggests that an analysis with larger samples of clergy representing various religious affiliations may reveal a statistically significant difference on the topic ratings based on religious affiliation. ${ }^{13}$

\section{Discussion}

Clergy believe that a wide range of topics are important to address in premarital counseling. However, the participants in this study indicated that certain topics were more important to address than others. The five topics that were rated as most important overall were (a) commitment to the marriage, (b) communication skills, (c) attitudes and beliefs toward marriage, (d) conflict resolution, and (e) the importance of spending time with one's partner. Although these topics received the highest ratings from participants, clergy rated all 23 topics that were included on the PCS as either "very important" or "somewhat important" to address in premarital counseling.

To some extent, the religious affiliation of clergy is related to the rela- 
tive importance they ascribe to premarital counseling topics. There were significant differences in the ratings of five topics-commitment to the marriage, conflict resolution, coping skills, parenting and children, and religion-based on participants' religious affiliations. Compared to Methodists, Baptists rated all five of these topics as more important to address in premarital counseling. The following other significant differences in topics ratings were found: (a) compared with Methodists, Roman Catholic clergy rated two topics-coping skills and parenting and children-as significantly more important to address; (b) compared with Nondenominational Christians, Roman Catholic clergy rated parenting and children as significantly more important to address; and (c) compared with Methodists, Non-denominational Christian clergy rated religion as a more important topic to address.

The ratings of all other topics, except for friendship and social support, may be related to providers' religious affiliations, as small effect sizes were found for these relationships. These topic ratings may have failed to reach statistical significance due to the small number of respondents who represented Methodists $(n=18)$, Non-denominational Christians $(n=16)$, and Roman Catholics $(n=15)$. This suggests that future research that includes a larger number of participants representing these religious affiliations may reveal more significant differences in the importance that clergy ascribe to topics based on religious affiliation. Together, these findings suggest that pastoral counselors may address different topics in premarital counseling based on their religious affiliation.

The findings of the present investigation related to the topics that clergy believe are important to address in premarital counseling are generally consistent with the previous research that has been done in this area. Specifically, the topics that clergy believed are most important included communication skills, conflict resolution skills, and commitment to the marriage, which are three of the topics that have been identified as being important by previous researchers. ${ }^{14}$ In addition, clergy deemed important other topics which have been identified less frequently by other researchers, such as attitudes and beliefs toward marriage and the importance of spending time with one's partner. It is important to note that all of the topics included in this investigation were given a high rating by the total sample of clergy. This may indicate indiscriminately positive responses to the topics included on the survey, suggesting that all topics may be important to address depending on the context of the counseling sessions.

Premarital counseling occurs within a broad, multifaceted contextincluding the development of the couple's relationship, religious traditions, the sociopolitical context, family-of-origin influences, and the cultural background. All of these contextual variables influence a counselor's approach to premarital counseling, as well as each couple's needs in preparing for marriage. This study provides preliminary evidence that the contextual variables surrounding a couple's engagement impact the topics that counselors and couples believe are important to address in premarital counseling, as evidenced by the relationship between participants' religious affiliations and some topic ratings. Further research should continue to examine the influence of other contextual variables on the process and outcomes of premarital counseling.

One important limitation to the generalization of these findings must be 
noted. Clergy who participated in this study practice premarital counseling in a state in which the government has established guidelines for premarital counseling programs, and other regional influences may have affected providers' responses to the survey. The Florida Statutes require that premarital counseling providers who register with their counties must address the following four topics with the couples they counsel: communication skills, conflict resolution, finances, and parenting and children..$^{15}$ Other states across the nation have implemented similar policies, although the requirements of these laws vary..$^{\text {th }}$ The extent to which premarital counselors are affected by premarital counseling-related public policies remains unclear. As one participant in this study stated, "It is my personal practice to only marry a couple after $6-8$ hours of premarital counseling even before the State instituted their endorsement." However, it is possible that providers' ratings of the importance of topics were influenced by the requirements of the law. Of the 23 topics, providers rated communication skills as the second most important topic, conflict resolution skills fourth, parenting and children sixth, and finances fifteenth. Further research should be done to examine whether clergy in different states ascribe similar ratings to premarital counseling topics.

Another limitation to the findings of this investigation is the small number of providers who represented various religious affiliations. Because the sample size was relatively small for the four denominations represented in the analysis of religious affiliation and topic ratings, effect sizes were calculated to determine the strength of the observed relationships. Although only five topics were rated significantly different based on participants' religious affiliation, all but one of the remaining topics demonstrated a small effect for the relationship. These findings provide preliminary evidence that premarital counselors believe it is important to address different topics in premarital counseling based on their religious affiliation. More research is needed to further examine these differences.

More research is also needed to examine inclusion criteria for the topics that may be addressed in premarital counseling programs. Because time limitations render it likely that not all possible topics can be addressed, future research should continue to examine which topics are most appropriate to address with which couples. Clergy rated all 23 topics included on the PCS as either "very important" or "somewhat important" to address in premarital counseling. Therefore, the needs of the couple may be most relevant in determining which topics are addressed in a premarital counseling session. Further research may examine how premarital counselors choose the topics they address, as well as identify the most effective strategies for doing so with diverse client populations.

Providers may choose which topics to discuss based on their own experience, training, and preferences. This study demonstrates that clergy value topics differently based on their religious affiliation. For example, Baptist and Methodist participants differed significantly in their ratings of the importance of five topics-commitment to the marriage, conflict resolution, coping skills, parenting and children, and religion. This suggests that premarital counseling practices mar differ across different religious denominations, although the source of these differences remains unclear. For example, these differences mav reflect diverse professional training practices, theological orientations, institutional regulations, cultural influences, and/or regional traditions. 


\section{Conclusion}

The findings of this study have three major implications for pastoral counselors who practice premarital counseling. First, a singular prescription to topics for premarital counseling is not possible. Previous research and the current findings suggest that premarital counseling topic preferences vary. Couples have a need to address the topics that are most relevant to their lives and to their relationships. The discussion of many different topics in premarital counseling may prove fruitful in helping clients to enhance their future marital relationships. Pastoral counselors, therefore, must select the topics that are most appropriate within the practical constraints-such as the length and format - of the premarital counseling session.

Second, it is necessary for pastoral counseling to maintain a flexible approach to discussing the topics that are most relevant to each couple during their time in premarital counseling. Carroll and Doherty suggest that standardized programs that include a fixed prescription of topics and formats may be less useful than programs that are targeted to the unique needs of couples. ${ }^{17}$ The clergy who participated in this study rated all of the possible 23 topics as being "very important" or "somewhat important" to address in premarital counseling. Based on the findings of this study, the average length of time that couples spend with clergy in premarital counseling is 8.79 hours. In this time-limited premarital counseling, it is likely to be impossible to address all of the topics that may be important for premarital couples. Maintaining flexibility allows the provider to address the topics that are most relevant to each couple.

Finally, pastoral counselors should become aware of the contextual factors that influence their work with premarital couples. Multiple contextual variables influence the decisions that pastoral counselors make in premarital counseling. Awareness of these variables allows counselors to develop premarital counseling programs that meet the needs of the clients they serve. Anc

\section{Endnotes}

* Please address correspondence regarding this article to the author at cemurray@uncg.edu

1. P. Fraenkel, H. Markman, \& S. Stanley, "The Prevention Approach to Relationship Problems," Sexual and Marital Therapy, 1997, Vol. 12, pp. 249-258; R. F. Stahmann and W. J. Hiebert, Premantal Counseling (Lexington, MA: Lexington Books, 1980).

2. B. Silliman and W. R. Schumm, "Improving Practice in Marriage Preparation," Journal of Sex and Marital Therapy, 1999, Vol. 25, pp. 23-24.

3. T. B. Holman, Premarital Predaction of Mantal Quality or Breakup: Research, Theory, and Practice (New York, NY: Kluwer Academic/Plenum Publishers, 2001).

4. Topics are draun from the following resources: G. Bodenmann, "Can Divorce Be Prevented by Enhancing the Coping Skills of Couples:" Journal of Divorce and Remarnage, 1997, Vol. 27, pp. 177-197; D. Douglas, M. Ferrer, D. Humphries, D. Peacock, \& M. Taylor, Before You Tue the Knot: Leader's Guide (Gainesville, FL: Cooperative Extension Service, Institute of Food and Agricultural Sciences, Lniversity of Florida, 2001); P. Fraenkel, H. Markman, \& S. Stanley; "The Prevention Approach to Relationship Problems,” Sexual and Mantal Therapy, 1997, Vol. 12, pp. 249-258; B. G. Guerney, Jr., Relationship Enhancement (San Francisco, CA: Jossey-Bass Publishers, 1979); T. B. Holman, Premartal Prediction of Martal Quality or Breakup: Research, 
Theory, and Practıce (New York, NY: Kluwer Academic/Plenum Publishers, 2001); M. H. Hoopes and B. L. Fisher. "A Premarital Education Program," in M. H. Hoopes, B. L. Fisher, \& S. H. Barlow (Eds.), Structured Family Facilitation Programs (Rockville, MD: Aspen Ststems Corporation. 1984), pp. 195-206; J. H. Larson, "You're Mv One and Onlv': Premarital Counseling for Unrealistic Beliefs about Mate Selection," The American Journal of Famuly Therapy, 1992, Vol. 20, pp. 242-253; W. E. Parish, "A Quasi-experimental Evaluation of the Premarital Assessment Program for Premarital Counseling," Australlan and New Zealand Jourmal of Famely Therapy, 1992, Vol. 13, pp. 33-36; M. N. Russell and R. F. Lyster, "Marriage Preparation: Factors Associated with Consumer Satisfaction," Family Relations, 1992, Vol. 41, pp. 446-45̌2; B. Silliman and IT. R. Schumm, "Improving Practice in Marriage Preparation," Journal of Sex and Marital Therapy, 1999, Vol. 25, pp. 23-43; R. F. Stahmann and W. J. Hiebert, Premantal Counseling (Lexington, MA: Lexington Books, 1980); R. F. Stahmann and C. J. Salts, "Educating for Marriage and Intimate Relationships," in M. E. Arcus, J. D. Schvanereldt, \& J. J. Moss (Eds.), Handbook of Family Life Educatıon, Volume 2 (Newburv Park, CA: Sage Publications, 1933), pp. 33-61; S. M. Stanley, "Making a Case for Premarital Education," Famıly Relations, 2001, Vol. 50, pp. 272-280; C. E. Valiente, C. J. Belanger, \& A. L'. Estrada, "Helpful and Harmful Expectations of Premarital Interventions," Journal of Sex and Marital Therapy, 2002, Vol. 28. pp. 71-77; L. M. Williams, "Premarital Counseling: A Needs Assessment among Engaged Couples," Contemporary Family Therapy, 1992, Vol. 14, pp. 505-518: L. M. Williams and L. A. Riley, "En Empirical Approach to Designing Marriage Preparation Programs," Amencan Journal of Family Therapy, 1999, Vol. 27, pp. 271284.

5. J. M. Curtis, "Motivational Techniques for Individual and Group Psychotherapv;" Psychological Reports, 1984, Vol. 54, pp. 271-277.

6. M. N. Russell and R. F. Lyster, "Marriage Preparation: Factors Associated with Consumer Satisfaction," Family Relatıons, 1992, Vol. 41, pp. 446-452.

7. R. F. Lyster, M. N. Russell, \& J. Hiebert, "Preparation for Remarriage: Consumers" V'iews," Joumal of Divorce and Remarriage, 1995, Vol. 24, pp. 143-157.

8. L. M. Williams and L. A. Riley, "An Empirical Approach to Designing Marriage Preparation Programs," American Journal of Family: Therapy, 1999, Vol. 27 , pp. 271-284.

9. G. S. Risch, L. A. Riley, \& M. G. Lawler, "Problematic Issues in the Early Years of Marriage: Content for Premarital Education." Journal of Psychology and Theology. 2003, Vol. 31, pp. 253-269.

10. E. F. Jones and R. F. Stahmann, "Clergr Beliefs, Preparation, and Practice in Premarital Counseling," The Journal of Pastoral Care, 1994, Vol. 48, pp. 181-186.

11. Florida Statutes, Sections 741.0305 and 741.04, "The Marriage Preparation and Preservation Act of 1998," retrieved on December 03, 2002, from http://wuw:flsenate.gov/

12. Randall Penfield, The Fundamentals of Survey-based Research (Gainestille, FL: Lniversity of Florida, 2003).

13. Randall Penfield, The Fundamentals of Survey-based Research (Gainesville, FL: Lniversity of Florida, 2003).

14. For example, see J. S. Carroll and W. J. Doherty, "Evaluating the Effectiveness of Premarital Prevention Programs: A Meta-analytic Review of Outcome Research," Family Relations, 2003, Vol. 52, pp. 105-118; G. S. Risch, L. A. Riley, \& M. G. Lawler, "Problematic Issues in the Early Years of Marriage: Content for Premarital Education," Journal of Psychology and Theology, 2003, Vol. 31, pp. 253-269; M. N. Russell and R. F. Lyster, "Marriage Preparation: Factors Associated with Consumer Satisfaction," Family Relations, 1992, Vol. 41, pp. 446-452; L. M. W'illiams and L. A. Riley, "An Empirical Approach to Designing Marriage Preparation Programs," American Journal of Family Therapy, 1999, Vol. 27, pp. 271-284.

15. Florida Statutes, Sections 741.0305 and 741.04, "The Marriage Preparation and Preservation Act of 1998," retrieved on December 03, 2002 from 
http://wuw.flsenate.gov/

16. For a review of state policies related to premarital counseling and marriage promotion, see K. Gardiner, M. Fishman, P. Nikolov, S. Laud, \& A. Glosser, State Policles to Promote Marriage, United States Department of Health and Human Services (2002). Retrieved May 12, 2003, from http://aspe.hhs.gov/hsp/hspparent.htm

17. J. S. Carroll and W. J. Doherty, "Evaluating the Effectiveness of Premarital Prevention Programs: A Meta-analytic Review of Outcome Research,” P, 2003, Vol. 52,

\section{C $P$ P $P$}

College of Pastoral Supervision and Psychotherapy, Inc.

A theologically based certifying and accrediting covenant community dedicated to "recovery of the soul," granting Diplomate status in pastoral psychotherapy and clinical supervision, and Pastoral Counselor status to parish pastors and institution chaplains.

Prospective students, as well as professionals seeking membership, should contact:

College of Pastoral Supervision and Psychotherapy, Inc.

The Reverend Raymond J. Lawrence, General Secretary

P. O. Box 162, Times Square Station, New York, NY 10108

○

Phone: 1-800-277-7521;e-mail: raymondlawrence@cpsp.org

Web Site: http://www.cpsp.org 


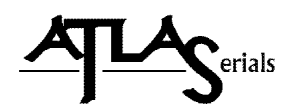

Copyright and Use:

As an ATLAS user, you may print, download, or send articles for individual use according to fair use as defined by U.S. and international copyright law and as otherwise authorized under your respective ATLAS subscriber agreement.

No content may be copied or emailed to multiple sites or publicly posted without the copyright holder(s)' express written permission. Any use, decompiling, reproduction, or distribution of this journal in excess of fair use provisions may be a violation of copyright law.

This journal is made available to you through the ATLAS collection with permission from the copyright holder(s). The copyright holder for an entire issue of a journal typically is the journal owner, who also may own the copyright in each article. However, for certain articles, the author of the article may maintain the copyright in the article. Please contact the copyright holder(s) to request permission to use an article or specific work for any use not covered by the fair use provisions of the copyright laws or covered by your respective ATLAS subscriber agreement. For information regarding the copyright holder(s), please refer to the copyright information in the journal, if available, or contact ATLA to request contact information for the copyright holder(s).

About ATLAS:

The ATLA Serials (ATLAS $®)$ collection contains electronic versions of previously published religion and theology journals reproduced with permission. The ATLAS collection is owned and managed by the American Theological Library Association (ATLA) and received initial funding from Lilly Endowment Inc.

The design and final form of this electronic document is the property of the American Theological Library Association. 